\title{
Perawatan gigi premolar kedua rahang atas dengan saluran akar bengkok menggunakan jarum NiTi rotary
}

\author{
Cyntia Ayu Rachmawati ${ }^{1}$, Anna Muryani ${ }^{2}$
}

\author{
${ }^{1}$ Poliklinik Gigi dan Mulut Rumah Sakit Dustira Cimahi, Indonesia \\ ${ }^{2}$ Departemen Konservasi Gigi, Fakultas Kedokteran Gigi Universitas Padjadjaran, Indonesia
}

*Korespondensi: anna.muryani@fkg.unpad.ac.id

Submisi: 15 Mei 2020; Penerimaan: 29 November 2020; Publikasi online: 30 November 2020

DOI: $10.24198 / j k g . v 32$ i2.27397

\begin{abstract}
ABSTRAK
Pendahuluan: Preparasi saluran akar dapat menjadi tantangan apabila dihadapkan pada morfologi sistem saluran akar yang kompleks. Gigi dengan saluran akar bengkok dapat menimbulkan kesulitan bagi dokter gigi dalam melakukan perawatan saluran akar. Perawatan saluran akar bengkok membutuhkan penggunaan alat, bahan dan teknik yang efektif untuk membersihkan saluran akar dengan baik. Tujuan laporan kasus ini adalah menjelaskan perawatan gigi premolar kedua rahang atas dengan saluran akar bengkok menggunakan jarum NiTi rotary. Laporan kasus: Pasien perempuan usia 16 tahun dengan rujukan dari bagian orthodontik untuk dirawat gigi kiri atas belakang yang berlubang besar dan terdapat benjolan pada gusi. Hasil pemeriksaan klinis terdapat karies besar pada gigi 25 , tes perkusi positif, tes palpasi positif, dan vitalitas negatif. Hasil Pemeriksaan radiologi terdapat gambaran radiolusen difus pada ujung apikal dan menunjukkan konfigurasi saluran akar bengkok sebesar $54^{\circ}$. Diagnosa gigi 25 adalah nekrosis pulpa disertai abses apikalis kronis. Isolasi daerah kerja, kemudian preparasi akses kavitas. Negosiasi saluran akar menggunakan K-files \#10 dan mengukur panjang kerja dengan apex locator. Saluran akar diirigasi dengan menggunakan $\mathrm{NaOCl}$ 2,5\% lalu diikuti oleh EDTA 17\%. Preparasi dilakukan dengan menggunakan instrument rotari hingga \#25.06. Medikamen saluran akar menggunakan kalsium hidroksida. Kunjungan berikutnya dilakukan pengisian saluran akar diikuti preparasi pasak fiber dan restorasi direk komposit. Simpulan: Perawatan gigi premolar kedua rahang atas dengan saluran akar bengkok menggunakan jarum NiTi rotary, dengan bahan irigasi Sodium hipoklorit dan EDTA diaktifasi agitasi sonik, serta medikamen kalsium hidroksida menunjukkan keberhasilan perawatan pada kunjungan kedua.
\end{abstract}

Kata kunci: Perawatan saluran akar, akar bengkok, premolar

\section{Treatment of the maxillary second premolar with a curved root canal using a rotary NiTi needle}

\section{ABSTRACT}

Introduction: Root canal preparation can be challenging when faced with the complex morphology of the root canal system. A curved root canal can make it difficult for root canal treatment, which requires the use of effective tools, materials, and technique to clean the root canal properly. This case report was aimed to describe the treatment of maxillary second premolar with a curved root canal using a rotary NiTi needle. Case report: A 16-year-old female patient who was referred from the orthodontics department for the treatment of the left maxillary second premolar with a large cavity and a gingival lump. The clinical examination results were extensive caries on tooth 25, positive percussion test, positive palpation test, and negative vitality. The radiological examination showed diffuse radiolucent images at the apical tip and showed a curved root canal configuration of $54^{\circ}$. Diagnosis of tooth 25 was pulp necrosis with chronic apical abscess. The working area was isolated, then the access cavity preparation was conducted. Root canal negotiation was carried out using the K-files \#10, and the working length measurement was conducted with the apex locator. The root canal was irrigated using the $2.5 \% \mathrm{NaOCl}$, followed by $17 \%$ EDTA. Preparation was carried out using the rotary instruments up to \#25.06. Root canal medicaments was using the calcium hydroxide. The root canal filling was performed in the next visit, followed by fiber post preparation and direct composite restoration. Conclusion: The treatment of maxillary second premolar with a curved root canal using a rotary NiTi needle, with irrigation agent of sodium hypochlorite and EDTA, activated by sonic agitation, and calcium hydroxide medicament, showed successful result at the second visit.

Keywords: Root canal treatment, curved root, premolar. 


\section{PENDAHULUAN}

Saluran akar bengkok sering ditemukan pada gigi posterior rahang atas. Premolar kedua rahang atas merupakan gigi dengan variasi anatomi terbanyak. Prevalensi akar bengkok premolar kedua rahang atas adalah 4,1\%., ${ }^{1,2}$ Akar bengkok merupakan anomali perkembangan yang menghasilkan angulasi tajam antara akar dan mahkota gigi. ${ }^{2,3}$

Faktor etiologi yang menjadi penyebab akar bengkok yaitu trauma mekanis gigi sulung, ketidakseimbangan perkembangan yang tidak diketahui, infeksi saluran akar, perkembangan ektopik benih gigi, dan kurangnya ruangan. ${ }^{3,4,5}$ Bentuk anatomi yang kompleks dan kelengkungan saluran akar dapat menjadi kendala dalam preparasi saluran akar yang ideal. Dokter gigi ditantang melakukan preparasi, pembersihan, disinfeksi, dan obturasi saluran akar untuk mencapai keberhasilan perawatan saluran akar. ${ }^{5,6}$

Pengetahuan mengenai bentuk anatomi dan kompleksitas sistem saluran akar diperlukan untuk mendapatkan hasil yang optimal ketika melakukan preparasi saluran akar.,5,5 Saluran akar panjang, sempit, dan melengkung paling rentan terhadap transportasi selama instrumentasi. Deformasi dan fraktur instrumen dalam saluran akar dapat menyebabkan masalah serius selama perawatan saluran akar. $4,6,7,8$ Strategi perawatan saluran akar bengkok dimulai dari evaluasi sebelum perawatan saluran yaitu melalui pemeriksaan penunjang radiografi. Arah masuk yang baik pada ruang pulpa menuju kontriksi apikal (glyde path) dan pembentukan sepertiga koronal saluran akar adalah langkah pertama menentukan keberhasilan pembetukan saluran akar bengkok. Preparasi yang baik pada sepertiga koronal dapat membantu pencapaian bentuk yang ideal pada dua pertiga saluran akar selanjutnya. ${ }^{2,3,4,5,6,7,8}$

Preparasi sepertiga koronal yang ideal akan memungkinkan larutan irigasi mencapai keseluruhan ruang saluran akar dan memungkinkan instrumentasi bagian sepertiga tengah dan sepertiga apikal tanpa adanya hambatan. $^{2} \quad$ Pendekatan preoperatif serta pemilihan teknik instrumentasi yang tepat penting untuk mencegah kesalahan prosedur seperti ledge, fraktur instrumen, pemampatan saluran akar, pembentukan zip dan elbow. ${ }^{6,9}$
Tujuan laporan kasus ini adalah menjelaskan perawatan gigi premolar kedua rahang atas dengan saluran akar bengkok menggunakan jarum NiTi rotary.

\section{LAPORAN KASUS}

Pasien perempuan usia 16 tahun datang ke RSGM UNPAD dengan rujukan dari bagian orthodontik untuk dilakukan perawatan saluran akar. Hasil pemeriksaan ekstra oral tidak ada kelainan. Hasil pemeriksaan intra oral pada gigi kiri belakang rahang atas yang berlubang besar dan terdapat benjolan pada gusi dengan diameter $5 \mathrm{~mm}$ dan sering mengeluarkan nanah. karies mencapai pulpa pada bagian proksimal dan oklusal hingga mencapai pulpa pada gigi 25 , tes vitalitas negatif, tes perkusi positif, tes palpasi positif, dan terdapat fistula di gingiva 25 (Gambar 1).

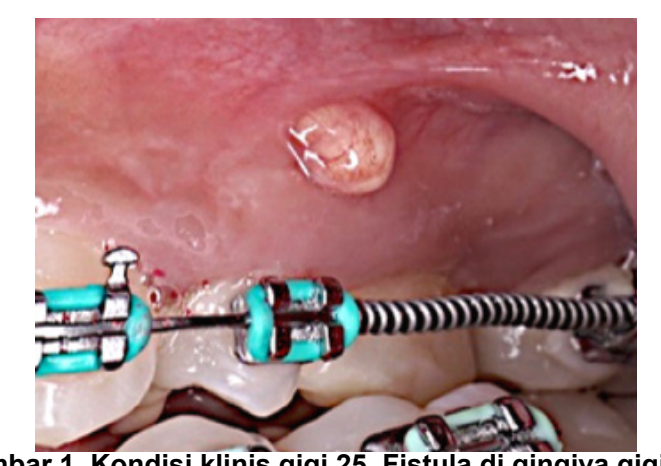

Gambar 1. Kondisi klinis gigi 25, Fistula di gingiva gigi 25. (Sumber: Dokumentasi pribadi)

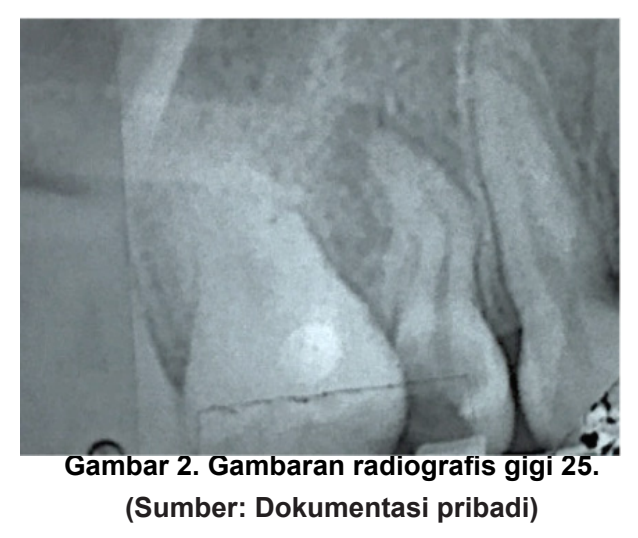

Hasil Pemeriksaan radiologi terdapat gambaran radiolusen pada bagian distal hingga mencapai pulpa serta radiolusen difus diameter 3 $\mathrm{mm}$ pada ujung apical. Konfigurasi saluran akar bengkok $54^{\circ}$ kearah distal (Gambar 2). Diagnosa gigi 25 adalah nekrosis pulpa disertai abses apikalis kronis. 
Penatalaksanaan kasus pada kunjungan pertama yaitu isolasi daerah kerja dengan menggunakan rubber dam, pembuatan preendodontic built up, preparasi akses kavitas menggunakan bur Endo Access (Dentsply, Germany) dan pelebaran orifis saluran akar dengan menggunakan Gates Giden Drill \#2 (Dentsply, Germany). Ruang pulpa diirigasi menggunakan larutan $\mathrm{NaOCl} 5,25 \%$ diikuti EDTA $17 \%$ dan saline.
Negosiasi saluran akar menggunakan precurved C-Pilot \#10 (VDW, Munich) dan panjang kerja diukur dengan apex locator (Dentsply, Germany). Glide path dilakukan hingga panjang kerja dengan menggunakan C-Pilot \#15, \#20, dan \#25 (VDW, Munich). Verifikasi patensi saluran akar menggunakan C-Pilot \#10 (VDW, Munich) untuk mencegah tersumbatnya saluran akar oleh debris (Gambar 3A \& B).

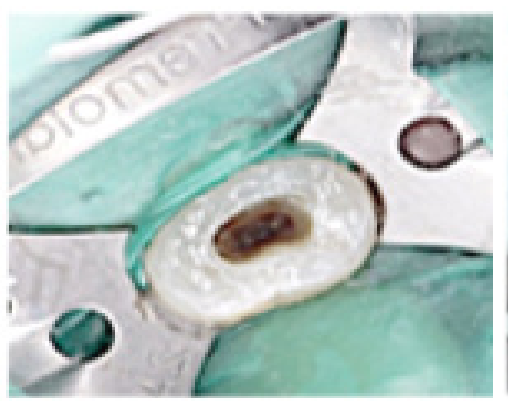

A

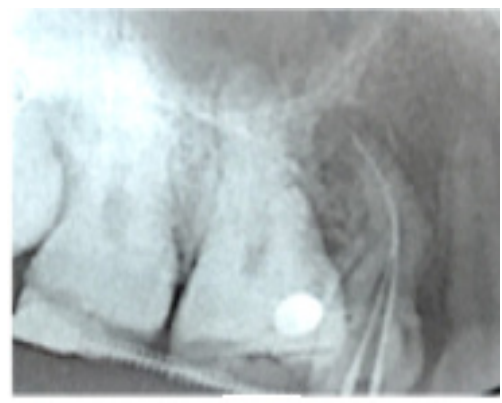

$B$

Gambar 3. A. Pre-endodontic build up dan open access; B. Apical patency dengan C-Pilot \#10. (Sumber: Dokumentasi pribadi)

Saluran akar diirigasi dengan menggunakan $\mathrm{NaOCI} 5,25 \%$ lalu diikuti oleh EDTA $17 \%$ dengan agitasi sonik setiap kenaikan nomor file. Preparasi dilanjutkan dengan menggunakan instrumen rotari Protaper Gold (Dentsply, Germany) hingga \#25.06. Apical patency dilakukan untuk mencegah penumpukan debris diujung saluran akar. Medikamen saluran akar menggunakan kalsium hidroksida dan ditutup dengan tumpatan sementara selama 2 minggu. Kunjungan kedua dilakukan pemeriksaan dan didapatkan hasil tidak terdapat keluhan pasien, tes perkusi dan palpasi memberikan hasil negatif, dan tidak terdapat sinus tract. Saluran akar diirigasi dengan $\mathrm{NaOCl}$ $5,25 \%$ diikuti dengan saline dengan agitasi sonik lalu dikeringkan dengan paper point streril. Foto periapikal uji coba master cone dilakukan dengan menggunakanguttapercha\#25,06(Gambar4A,B,C)

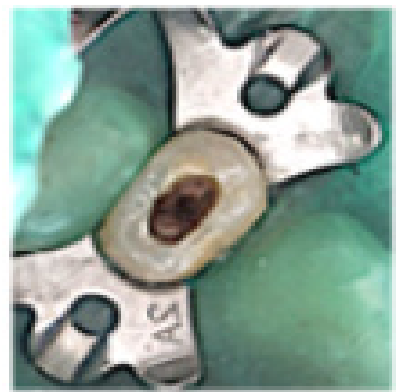

A

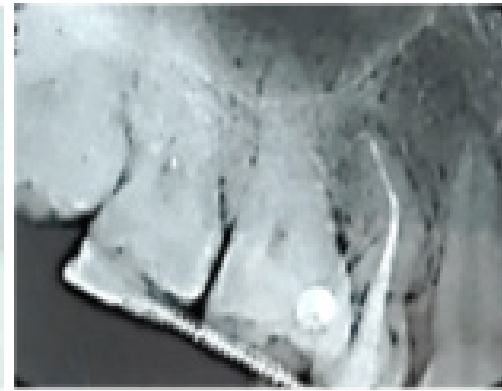

B

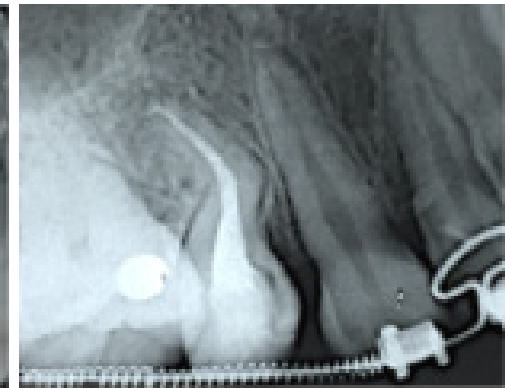

C

Gambar 4. A. Pengisian gigi 25; B. Foto radiografis trial pengisian; C. Pengisian saluran akar gigi. (Sumber: Dokumentasi pribadi)

Pengisian saluran akar dengan metode cold lateral condensation dilakukan dengan menggunakan resin based sealer $\mathrm{AH}$ Plus (Dentsply, Germany) dan gutta percha lalu ditutup dengan tumpatan sementara.

Kunjungan berikutnya dilakukan preparasi pasak fiber dan restorasi komposit secara langsung sebagai long term temporary restoration karena pasien masih dalam perawatan orthodontic (Gambar 5A \& B). Pasien menyetujui kasusnya untuk dipublikasikan dengan menandatangani informed consent. 


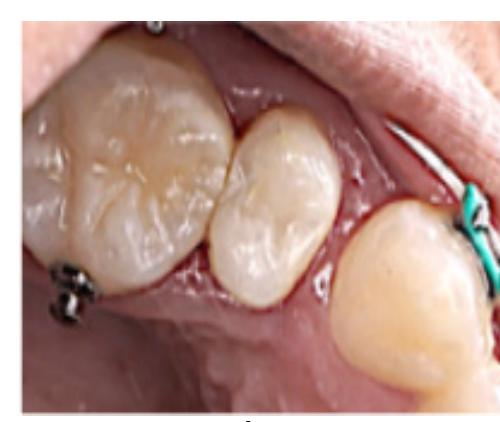

A

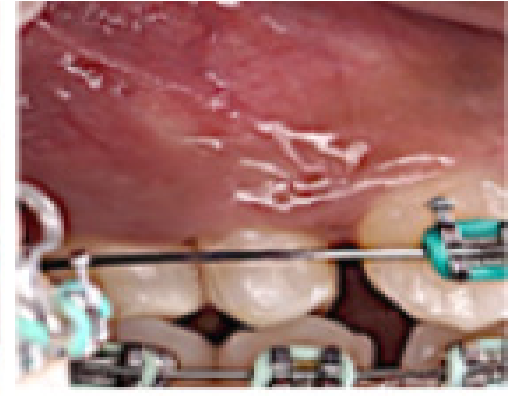

B

Gambar 7. Long term temporary restoration dengan pasak fiber dan resin komposit: A. Oklusal; B. Bukal.

(Sumber: Dokumentasi pribadi)

\section{PEMBAHASAN}

Ketidakseimbangan tahapan pembentukan gigi yang menghasilkan deviasi dari hubungan linear mahkota dengan akar gigi merupakan pengertian gigi dengan konfigurasi akar bengkok. Penyebab akar bengkok ini masih belum jelas. Etiologi yang paling umum yaitu trauma mekanis pada gigi sulung sehingga menghasilkan kerusakan benih gigi permanen, selain itu juga adanya gangguan perkembangan benih gigi, infeksi, dan perkembangan ektopik benih gigi. ${ }^{2,4,10}$

Prevalensi akar bengkok sangat tergantung pada penilaian subyektif tentang angulasi normal dan angulasi tidak normal. Semua akar gigi mempunyai kelengkungan sehingga istilah akar bengkok merupakan kelengkungan akar berlebih atau tidak normal yang dapat menyulitkan prosedur endodontik atau pencabutan.,8 Gigi dengan akar lurus dan saluran akar gigi yang juga lurus sebenarnya merupakan hal yang tidak umum ditemukan karena mayoritas gigi memiliki kelengkungan saluran akar bahkan sebagian besar memiliki beberapa bidang kelengkungan di sepanjang saluran akarnya. Vertucci ${ }^{11}$ mengemukakan bahwa gigi premolar rahang atas adalah gigi dengan variasi anatomi terbanyak. ${ }^{2,5,7,11}$

Prevalensi gigi premolar kedua rahang atas adalah $1,23 \%$ terbanyak pada gigi rahang atas. ${ }^{4}$ Kasus ini, gigi premolar dua kiri rahang atas yang dirawat memiliki saluran akar bengkok.

Pengetahuan tentang anatomi akar dalam kasus ini sangat penting untuk menemukan dan menegosiasi saluran akar sehingga dapat dilakukan debridemen secara menyeluruh dan untuk mencegah kesalahan diagnosis serta kesalahan selama instrumentasi yang akan mempengaruhi tingkat keberhasilan perawatan endodontik. Kurvatur saluran akar harus dipahami sebelum memulai perawatan endodontik untuk memudahkan penggunaan instrumen endodontik yang tepat dan aman. ${ }^{4,7,12}$ Cara untuk mendeteksi morfologi saluran akar dalam kasus ini adalah penggunaan radiografi sebelum perawatan.,7,13 Radiografi periapikal digunakan dalam kasus ini sebagai sarana penting dalam diagnosis endodontik. Perencanaan perawatan saluran akar terkait dengan identifikasi berbagai aspek yang diamati dalam gambar radiografi, termasuk kompleksitas anatomi, bahan saluran akar, gangguan perkembangan gigi, dan periodontitis apikal. Beberapa studi menyarankan metode untuk menentukan lengkung saluran akar menggunakan radiografi periapikal dari beberapa sudut. ${ }^{14-16}$

Beberapa klasifikasi lengkung saluran akar menggunakan definisi seperti curve, gradual curve, sickle shape curve, severe-moderate-straight curve, bayonet curve, dilacerated curve. .,9,14 $^{2}$

Schneider ${ }^{9,14,17,18}$ mendeskripsikan metode yang dapat diandalkan untuk menentukan lengkung saluran akar. Metode Schneider digunakan dalam kasus ini untuk untuk menentukan kelengkungan

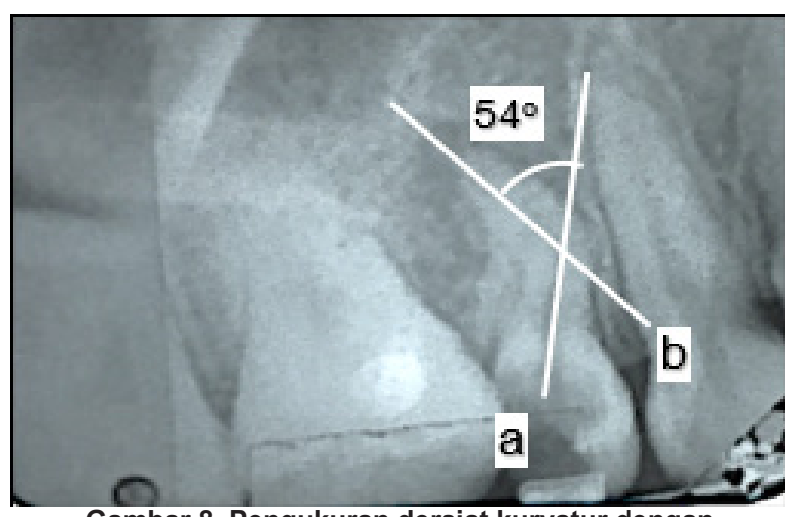

Gambar 8. Pengukuran derajat kurvatur dengan menggunakan metode Schneider. (Sumber: Dokumentasi pribadi) 
yaitu sudut yang diperoleh dari perpotongan dua garis lurus. Garis pertama ditarik dari orifis sejajar dengan sumbu panjang saluran akar dan garis kedua ditarik dari foramen apikal sampai memotong garis pertama pada titik dimana terdapat lengkungan. Sudut yang terbentuk ( $\alpha$ ) dinamai sesuai dengan tingkat kelengkungan saluran akar, yaitu; straight $\left(5^{\circ}\right)$, moderate $\left(10^{\circ}-20^{\circ}\right)$, dan severe $\left(25^{\circ}-70^{\circ}\right) .{ }^{9,14,18,19}$

Metode Schneider ini digunakan karena metode ini telah diterima secara universal karena sederhana dalam menentukan derajat lengkung saluran akar. ${ }^{20,21}$ Dobo-Nagy dkk. ${ }^{9}$ mengemukakan klasifikasi kelengkungan saluran akar, yaitu; I (lurus), J (kurva pada apikal), C (seluruh saluran akar melengkung) atau $S$ (multicurved). Pruett dkk. ${ }^{12}$ melaporkan bahwa efek jari-jari kelengkungan sebagai variabel independen harus dipertimbangkan dalam penelitian untuk mengevaluasi instrumentasi saluran akar.9,12,14,19 Kasus ini menggunakan metode Schneider untuk menentukan derajat kelengkungan saluran akar dan didapatkan hasil sudut kurvatur sebesar $54^{\circ}$.

Keberhasilan perawatan saluran akar pada kasus ini sangat bergantung pada efek pembersihan biomekanis saluran akar dan eliminasi mikoorganisme secara menyeluruh dari sistem saluran akar. Preparasi saluran akar yang memiliki kelengkungan merupakan salah satu tantangan terbesar dan menyulitkan dalam perawatan endodontik. ${ }^{7,15,16,22,23}$

Tahapan preflaring pada sepertiga koronal saluran akar dengan mengorbankan struktur gigi untuk mengurangi sudut kelengkungan sehingga mempermudah proses negosiasi saluran akar. Derajat kelengkungan saluran akar harus ditentukan sebelum memulai perawatan endodontik. Pelebaran sepertiga koronal dapat mengurangi hambatan instrumentasi bagian koronal, memudahkan pengukuran panjang kerja, dan memudahkan larutan irigasi masuk kedalam saluran akar. $4,7,11,13,24$

Kasus ini menggunakan Gates Giden Drill \#2 untuk melebarkan orifis saluran akar sehingga didapatkan akses garis lurus ke dalam saluran akar. ${ }^{9,13,24}$ Instrumentasi saluran akar bengkok pada kasus ini dipengaruhi oleh beberapa faktor, seperti fleksibilitas dan diameter instrumen, teknik instrumentasi, lokasi foramen, dan kekerasan dentin. Peluang perforasi sangat tinggi di saluran akar bengkok. Insidensi kesalahan prosedural dapat dikurangi dengan mengurangi tekanan penggunaan file dengan cara membengkokkan file yang lurus terhadap permukaan dentin yang melengkung dan mengurangi panjang file. Penurunan tekanan dapat dilakukan dengan precurving file karena dapat melintasi lengkung lebih baik daripada file lurus dan penggunaan file yang lebih kecil supaya dapat mengikuti lengkung saluran akar karena sifat fleksibilitasnya. File ukuran kecil harus dibuat tidak sempit di dalam saluran akar sebelum menggunakan file yang lebih besar dalam negosiasi. Penggunaan file ukuran sedang memungkinkan transisi ukuran instrumen lebih lancar sehingga menyebabkan pemotongan dinding saluran akar lebih halus. 7,25

C-Pilot stainless steel \#10 pada kasus ini digunakan sebagai alternatif dalam negosiasi saluran akar yang sempit dan melengkung dengan manfaat tambahan yaitu kekakuan dan fleksibilitas. Precurving instrumen tangan dan penggunaan ukuran file yang lebih kecil dapat memudahkan negosiasi saluran akar yang bengkok dan menjaga bentuk saluran akar dengan baik sehingga mengurangi kesalahan prosedural. Semua instrumen tangan dilakukan dengan teknik balanced forced yang memiliki keuntungan yaitu mengurangi ekstrusi debris, mengurangi kesalahan iatrogenik, dan menjaga instrumen tetap berada ditengah saluran akar. ${ }^{24-26}$

Pembersihan dan pembentukan saluran akar merupakan salah satu fase terapi endodontik yang paling penting pada kasus ini. Tujuan instrumentasi saluran akar adalah untuk memperoleh saluran tapered mengikuti bentuk saluran akar asli dari koronal ke apikal. Glide path merupakan langkah awal preparasi saluran akar. Pembentukan dan pembersihan saluran akar menjadi tidak dapat diprediksi atau mustahil tanpa diawali dengan glide path. Glide path endodontik merupakan saluran halus yang dibentuk dari orifis hingga konstriksi apikal. Ukuran minimal glide path harus berupa file endondontik \#10 yang longgar. Langkah in penting untuk mencegah kerusakan instrumen atapun kesalahan instrumentasi dan sebaiknya dilakukan sebelum dilakukan preparasi dengan menggunakan instrument rotari. ${ }^{26}$ File hand use stainless steel digunakan untuk membantu menciptakan glide path. Gerakan pasif dengan sentuhan ringan diperlukan untuk menghilangkan 
jaringan pulpa dan negosiasi anatomi apikal. ${ }^{12}$

Instrumen putar dengan file NiTi pada kasus ini memerlukan glide path karena kebanyakan file NiTi rotari mempunyai tip non-cutting dan tidak dapat menegosiasi saluran akar karena tingkat kelenturannya. Glide path memberi gambaran mengenai kelengkungan saluran akar dengan memvisualisasikan file setelah ditarik dari saluran akar dengan hati-hati. Pembuatan glide path harus dibuat dengan file hand use stainless steel fleksibel dengan nomor kecil untuk memastikan bahwa akan ada ruang yang cukup untuk instrumen rotari mengikuti saluran akar. Platino dkk..$^{27}$ juga melaporkan bahwa tingkat kerusakan instrumen rotari NiTi berkurang secara signifikan ketika penggunaannya didahului oleh glide path. Kasus ini juga menggunakan instrument tangan C-Pilot \#15, \#20, dan \#25 untuk mendapatkan glide path.

Penggunaan file rotari nikel titanium (NiTi) dengan teknik crown down membantu pelebaran sepertiga koronal, mengurangi binding instrument dibagian koronal, memberikan akses yang lebih baik ke bagian sepertiga apikal, mengurangi ekstrusi debris ke apikal, dan keefektifan irigasi di sepertiga apikal saluran akar. ${ }^{25,27}$ Paduan NiTi terdiri dari $55 \%$ nikel dan $45 \%$ titanium. Fleksibilitas file ini meningkat secara substansial dibandingkan dengan instrumen stainless steel.

Elastisitas paduan $\mathrm{NiTi}$ memungkinkan peningkatan penggunaan instrumen mekanis untuk pembentukan saluran akar. Instrumen NiTi memungkinkan preparasi saluran yang lebih terpusat dengan transportasi yang lebih sedikit dan kurangnya penyimpangan saluran akar. Teknik instrumentasi yang melibatkan aksi rotasi biasanya menyebabkan lebih sedikit ekstrusi debris daripada teknik manual dengan linier filing movement. Jumlah debris dari foramen apikal yang diproduksi dengan instrumentasi teknik step back (2,58 $\mathrm{mg}$ ) lebih besar daripada debris yang diproduksi dengan instrumentasi lain seperti instrumen putar $\mathrm{NiTi}(<0,5 \mathrm{mg}) \cdot{ }^{27}$

Instrumen berbasis NiTi dilaporkan sangat cocok untuk preparasi saluran akar melengkung. Panduan NiTi menunjukkkan perilaku sangat elastis sehingga dapat kembali ke bentuk aslinya setelah terjadi deformasi. Studi melaporkan bahwa file NiTi lebih efektif mempertahankan kelengkungan saluran akar yang asli..29 Saluran akar dengan kelengkungan ekstrim membutuhkan penggunaan file NiTi supaya dapat secara efektif membersihkan saluran akar tanpa terjadi kerusakan instrumen ataupun transportasi saluran akar. ${ }^{2}$ Instrumentasi dengan instrumen $\mathrm{NiTi}$ menghasilkan bentuk saluran yang lebih tepat. ${ }^{29}$ Sistem file yang digunakan pada kasus ini adalah Protaper Gold (Dentsply, Germany). Sistem ini mempunyai file yang lebih fleksibel dan memiliki pemotongan kurang agresif yang secara efisiensi dan efektif mengurangi terjadinya kesalahan selama preparasi biomekanik khususnya pada saluran akar bengkok. ${ }^{7}$

Instrumentasi pada sistem saluran akar pada kasus ini harus selalu didukung oleh penggunaan cairan irigasi antimikroba. Meskipun kemajuan teknologi mampu membentuk saluran akar, setidaknya $35 \%$ dari permukaan saluran akar masih tetap tidak terinstrumentasi, dan pembersihan saluran akar dalam hal pembuangan jaringan lunak dan eliminasi bakteri sangat bergantung pada kemampuan larutan irigasi kimia aktif untuk kompleksitas anatomi saluran akar. ${ }^{28}$

Sodium hipoklorit (NaOCl) 5,25\% merupakan bahan irigasi yang dianggap paling ideal untuk digunakan di seluruh instrumentasi karena memiliki efek antimikroba yang kuat dan aktivitas proteolitik sehingga digunakan sebagai larutan irigasi pada kasus ini. $\mathrm{NaOCl}$ memiliki kemampuan unik untuk menghancurkan jaringan nekrotik serta komponen organik dari smear layer. Ethylene diamine tetraacetic acid (EDTA) 17\% merupakan bahan chelating yang dapat menghilangkan ion kalsium untuk mendemineralisasi komponen anorganik dentin. Irigasi EDTA telah dianjurkan untuk menghilangkan smear layer yang disebabkan oleh instrumentasi saluran akar.

Studi mengenai pengangkatan smear layer menunjukkan bahwa $\mathrm{NaOCl}$ tidak dapat membersihkan komponen anorganik smear layer. Irigasi EDTA sendiri juga tidak dapat sepenuhnya membersihkan komponen organik smear layer. Cara yang paling efektif untuk menghilangkan smear layer adalah dengan kombinasi EDTA dan $\mathrm{NaOCl}$ dimana dapat mengangkat komponen organik dan anorganik. ${ }^{28-30}$ EDTA diusulkan sebagai larutan yang dapat membantu dalam proses instrumentasi saluran akar yang sempit oleh Ostby ${ }^{29}$ pada tahun 1957. Penelitian Muryani, dkk. ${ }^{30}$ menujukkan pembersihan larutan EDTA yang signifikan dari 5 detik pertama irigasi sampai 60 detik terhadap 
pemnbersihan kalsium hidroksida didalam saluran akar.Larutan EDTA dapat mengelasi ion kalsium dari dentin dan membuat dentin menjadi lebih halus dan mudah dipreparasi.

Kalsium hidroksida $\left(\mathrm{Ca}(\mathrm{OH})_{2}\right)$ adalah bahan yang bersifat basa kuat dengan $\mathrm{pH}$ antara 1112,8. Pasta $\mathrm{Ca}(\mathrm{OH})_{2}$ di dalam saluran akar akan terurai menjadi $\mathrm{Ca}^{2+}$ dan $\mathrm{OH}^{-}$(hidroksil). Gugus $\mathrm{OH}^{-}$akan menyebabkan $\mathrm{pH}$ meningkat sehingga suasana di sekitarnya menjadi basa,yang akan mengaktifkan enzim hidrolitik alkalin phosphatase yang berhubungan dengan proses mineralisasi jaringan dan membuat bakteri tidak bisa hidup. ${ }^{31-32}$ Kalsium hidroksida yang menetralisir asam laktat dari osteoklas dan mencegah pelarutan komponen mineral gigi mampu mendorong terjadinya perbaikan dan kalsifikasi aktif. Proses ini dimulai dari respon degeneratif yang langsung diikuti dengan respon mineralisasi dan osifikasi. ${ }^{32,33}$

Kalsium hidroksida memecah protein bakteri yang terdapat di saluran akar dan mengurangi toksiksitasnya. Kalsium hidroksida berdifusi melalui tubuli dentin dan dapat berhubungan dengan ruang ligamen periodontal untuk menahan resorpsi akar eksternal dan mempercepat penyembuhan. Ion Kalsium bekerja dengan cara memberikan efek terapeutik pada jaringan sekitarnya berupa stimulasis seluler, migrasi sel, proliferasi sel, dan mineralisasi. Ion kalsium akan bertemu dengan ion karbondioksida $\left(\mathrm{CO}_{2}\right)$ dan ion karbonat $\left(\mathrm{CO}_{3}\right)$ dan berubah menjadi kalsium karbonat yang berperan dalam mineralisasi jaringan. Efektivitas antimikroba dalam kalsium hidroksida adalah melalui kemampuan mengabsorbsi karbon dioksida dalam saluran akar yang penting bagi bakteri saluran akar sehingga mikroba yang tergantung pada karbon dioksida tidak akan bertahan dalam saluran akar. $^{13,14,15,16,17,18,19}$

Agitasi sonik (Endoactivator, Dentsply) memiliki tujuan untuk meningkatkan efektifitas irigan dalam membersihkan sistem saluran akar (fenomena hidrodinamik). Fenomena hidrodinamik telah diidentifikasi sebagai cara yang dapat meruntuhkan perlekatan lapisan smear. Tujuan agitasi cairan adalah untuk menghasilkan kavitasi, aliran akustik dan aliran mikro dengan aman pada irigan-irigan di dalam saluran akar. ${ }^{35,36}$ Penelitian Muryani, dkk. ${ }^{37}$ membuktikan irigasi dengan bahan irigasi dengan dibantu agitasi sonik terbukti lebih efektif menghilangkan $\mathrm{Ca}(\mathrm{OH})_{2}$ dari saluran akar irregular daripada dengan teknik agitasi manual. ${ }^{37}$ Pada kasus ini agitasi sonik ini juga dapat membantu mengangkat residu $\mathrm{Ca}(\mathrm{OH})_{2}$ yang lama sebelum pengisian saluran akar.

\section{SIMPULAN}

Perawatan- gigi premolar kedua rahang atas dengan saluran akar bengkok menggunakan jarum NiTi rotary, dengan bahan irigasi Sodium hipoklorit dan EDTA diaktifasi agitasi sonik, serta medikamen kalsium hidroksida menunjukkan keberhasilan perawatan pada kunjungan kedua.

\section{DAFTAR PUSTAKA}

1. Dudeja PG, Dudeja KK, Garg A, Srivastava D, Grover S. Management of a previously treated, calcified, and dilacerated maxillary lateral incisor: A combined nonsurgical/surgical approach assisted by cone-beam computed tomography. J Endod 2016; 42(6): 984-8. DOI:10.1016/i.joen.2016.03.020

2. Khan R, Gupta M, Samant PS. Negotiating the double curvature. Int Dent J Student Res 2017; 5(2): 61-5. DOI: 10.18231/22783784.2017.0013

3. Gargi Mitra, Vikram Sharma, Jyoti Sachdeva, Mamta Singla, Kanica Taneja AB. To evaluate and compare canal transportation, canalcentering ability, and vertical root fracture resistance of teeth prepared with three different rotary file systems: An in vitro study. Endodontology 2017; 29(1): 53-9. DOI: 10.4103/endo.endo_33_17

4. Colak H, Bayraktar Y, Hamidi MM, Tan E, Colak T. Prevalence of root dilacerations in Central Anatolian Turkish dental patients TTPrevalencia de las dilaceraciones radiculares en pacientes dentales turcos de la región de Anatolia Central. West Indian Med J 2012; 61(6): 635-9.

5. Das UK, Mukherjee S, Maiti N. Managing the Risky Curve - A Case Report. Int J Clin Dent Sci. 2013;7-9.

6. Estrela C, Holland R, Estrela C, Alencar AHG. Characterization of Successful Root Canal Treatment. Brazilian Dent J 2014; 25(1): 3-11. DOI: 10.1590/0103-6440201302356.

7. Chowdhury D, Bhaumik T, Desai P. Endodontic 
Management of Maxillary First Premolar with S-Shaped Canals . Imperial Journal of Interdisciplinary Research (IJIR). 2017; 3(2): 1538-40.

8. Kluwer W, Negotiating the bends: An endodontic management of curved canals - A case series. Endodontology.2017;29:2:161-3

9. Balani P, Niazi F, Rashid H. A brief review of the methods used to determine the curvature of root canals. J Restor Dent. 2016; 3(3): 57. DOI:10.4103/2321-4619.168733.

10. Andreasen JO, Andreasen FM. Andersson L. $5^{\text {th }}$ ed. Textbook and Color Atlas of Traumatic Injuries to the Teeth. United states: Wiley Blackwell. 2018. p. 1064

11. Rotstein I, Ingle JI. Ingle's. Endodontics 7. $7^{\text {th }}$ ed. USA: PMHP USA Ltd. 2019. p. 963-80

12. Bogle J. Endodontic Treatment of Curved Root Canal Systems. Oral Heal J. 2014;6(May):1-7.

13. Ansari I, Maria R. Managing curved canals. Contemp Clin Dent. 2012; 3(2): 237. DOI:10.4103/0976-237X.96842

14. Estrela C, Bueno MR, Sousa-Neto MD, Pécora JD. Method for determination of root curvature radius using cone-beam computed tomography images. Braz Dent J 2008; 19(2): 114-8. DOI: 10.1590/s0103-64402008000200005

15. Bansal R. S-shaped Canals 1. J Dent Sci Oral Rehab. 2016; 7(3): 152-154.

16. Sakkir N, Thaha KA, Nair MG, Joseph S, Christalin R. Management of dilacerated and s-shaped root canals - An endodontist's challenge. J Clin Diagnostic Res. 2014; 8(6): 22-5. DOI: $10.7860 / J C D R / 2014 / 9100.4520$.

17. Hartmann RC, Fensterseifer M, Peters OA, Fiqueiredo JAP, Gomes MS, Rossi Fedele G. Methods for measurement of root canal curvature: a systematic and critical review. IEJ. 2018; 52(2): 1-12. DOI: 10.1111/iej.12996

18. Choi MR, Moon YM, Seo MS. Prevalence and features of distolingual roots in mandibular molars analyzed by cone-beam computed tomography. Imaging Sci Dent. 2015; 45(4): 221-6. DOI: $10.5624 /$ isd. 2015.45.4.221.

19. Dannemann M, Kucher M, Kirsch J, Binkowski A, Modler N, Hannig C, Weber MT. An Approach for a Mathematical Description of Human Root Canals by Means of Elementary Parameters. $J$ Endod. 2017; 43(4): 536-543. DOI: 10.1016/j. joen.2016.11.011.
20. Malur M, Chandra A. Schneider angle along with curvature height and distance - a new paradigm inthe measurement of root canal curvature and its comparison with canal access angle. International Journal Of Scientific Research. 2017; 6(5): 280-2. DOI: $10.36106 /$ ijs $r$

21. Kiamars Honardar, 1 Hadi Assadian, 1 Shahriar Shahab,2 Zahra Jafari,3 Ali Kazemi,4 Kiumars Nazarimoghaddam. Cone-beam Computed Tomographic Assessment of Canal Centering Ability and Transportation after Preparation with Twisted File and Bio RaCe Instrumentation. J Dent (Tehran). 2014l; 11(4): 440-46.

22. Sezavar M, Bohlouli B, Farhadi S. Simvastatin Effects on Dental Socket Quality: A Comparative Study. Content Clin Dent. 2018; 9 (1): 55-9. DOI: 10.4103/ccd.ccd 71917.

23. Hargreaves KM, Berman LH, Rotstein I. $11^{\text {th }}$ ed. Cohen's pathways of the pulp. Mosby : St Louis. 2020. p. 928

24. Park SY, Cheung GSP, Yum J, Hur B, Park JK, Kim HC. Dynamic Torsional Resistance of Nickel-Titanium Rotary Instruments. J Endod 2010;36(Issue 7):1200-04.

25. Hegde MN, Lagisetti AK, Honap MN. Negotiating the bends: An endodontic management of curved canals - A case series. Endodontology [serial online] 2017; 29(1): 1603. DOI: 10.4103/endo.endo_41_17

26. Dhingra A, Neetika. Glide path in endodontics. Endodontology 2014; 26(1): 217- 22.

27. Passi S, Kaler N, Passi N. What is a glide path?. Saint Int Dent J 2016; 2(1): 32-7. DOI: $10.4103 / 2454-3160.202220$

28. Nurliza C, Abidin T, Gigi DK, Gigi FK, Utara US. Prinsip-Prinsip Dasar Preparasi Saluran Akar ( Basic Principles of Chemomechanical Preparation of Root. Dentika Dent J. 2014; 18(2): 177-84.

29. Yudistian I. Perawatn obstruksi saluran akar menggunakan EDTA pada gigi paska restorasi amalgam. Interdent J Ked Gig. 2019; 15(2): 7073. DOI: $10.46862 /$ interdental.v15i2.595

30. Muryani A, Dharsono HDA, Zuleika Z, Moelyadi IMA, Prisinda D. Streamline characteristics using the computational fluid dynamic analysis in the flow of $18 \%$ EDTA irrigation solution to remove $\mathrm{Ca}(\mathrm{OH}) 2$. Maj Kedokt Gigi Indones. 2019; 4(2): 67. DOI: $10.22146 /$ 


\section{majkedgiind.30886.}

31. Mandhotra P, Goel M, Kulwant R, Verma $S$, Thakur V, Chamdel N. Accelerated Non Surgical Healing of Large Periapical Lesions using different Calcium Hydroxide Formulations: A Case Series. IJOHMR. 2016; 3(4): 79-83.

32. Holland R, Gomes JE, Cintra LT, Queiroz IO, Estrela C. Factors affecting the periapical healing process of endodontically treated teeth. J Appl Oral Sci. 2017; 25(5): 465-76. DOI: 10.1590/1678-7757-2016-0464.

33. Fernandes $M$, de Ataide I. Nonsurgical management of periapical lesions. J Conserv Dent. 2010; 13(4): 240-5. DOI: 10.4103/09720707.73384.

34. Dixit S,Dixit A,Kumar P. Nonsurgical Treatment of Two Periapical Lesions with
Calcium Hydroxide Using Two Different Vehicles.Hindawi. 2014; 4(1): 1-4. DOI: 10.1155/2014/901497

35. Siqueira JF. Treatment of endododontic infections. 2011. $1^{\text {st }}$ ed. Berlin:Quintessence. 2011. p. 416

36. Roda RS, Gettleman BH. Non surgical retreatment dalam Cohen, S., K.M. Hargreaves. Pathway of the Pulp. $10^{\text {th }}$ ed. Ed. St. Louis:Mosby Eslsevier. 2011. Chapter 25. Hal 175-184.

37. Muryani A, Hayati AT, Adang RAF. Comparison of the removal of calcium hydroxide medicaments on the root canal treatment irrigated with manual and sonic agitation technique . Padj J Dent. 2017;29(3):158-164. DOI: 10.24198/pjd.vol29no3.14479 